\title{
Sistem Deteksi Kelainan Neuromuscular Menggunakan Adaptive Neuro Fuzzy Inference System dan Dekomposisi Wavelet Elektromyogram
}

\author{
Nuryani $^{\# 1}$, Iftita Ida Sofia ${ }^{\# 2}$, Mohtar Yunianto ${ }^{\# 3}$

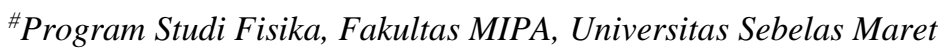 \\ Jl. Ir. Sutami 26A, Surakarta \\ ${ }^{1}$ nuryani@mipa.uns.ac.id \\ 2iftitaidasofia@student.uns.ac.id \\ 3mohtaryuniantodstaff.uns.ac.id
}

\begin{abstract}
Abstrak-Sistem neuromuscular terdiri dari saraf motorik dan otot rangka yang menghasilkan aktivitas kelistrikan pada otot dan menyebabkan otot dapat berkontraksi dan menghasilkan gerak tubuh. Gangguan neuromuscular dapat terjadi pada sel saraf yang dinamakan Neuropathy dan pada sel otot yang dinamakan Myopathy. Aktivitas kelistrikan pada otot direkam melalui suatu alat yang dinamakan Electromiography (EMG). Pada penelitian ini dilakukan identifikasi sinyal EMG pasien sehat, myopathy dan neuropathy. Neuropathy merupakan gangguan yang disebabkan oleh kerusakan sel saraf. Myopathy merupakan gangguan yang disebabkan oleh kerusakan sel otot. Penanganan dan pengobatan myopathy dan neuropathy berbeda, sehingga diperlukan suatu metode yang dapat mendiagnosis dengan tepat jenis gangguan yang dialami. Analisis karakteristik sinyal EMG dilakukan menggunakan metode dekomposisi Wavelet Discrete Dyadic dan variasi fitur Root Mean Square (RMS), approximate entropy, spectral entropy dan Singular Value Decompotition (SVD) entropy. Sinyal karakteristik yang diperoleh di identifikasi menggunakan metode klasifikasi Adaptive Neuro Fuzzy Inference System (ANFIS). Performa ANFIS dalam mengidentifikasi karakteristik sinyal EMG pada masing-masing koefisien dekomposisi, menghasilkan performa terbaik pada koefisien aproksimasi ke-5 (cA5), dengan akurasi $100 \%$, sensitivitas $100 \%$ dan spesivitas $100 \%$.
\end{abstract}

Kata kunci- EMG, Myopathy, Neuropathy, DWT, ANFIS

\section{Pendahuluan}

Aktivitas manusia dalam kehidupan melibatkan sistem gerak tubuh. Tubuh dapat bergerak diakibatkan oleh adanya aktivitas kelistrikan pada otot rangka. Aktivitas kelistrikan pada otot dihasilkan melalui perintah otak dalam bentuk potensial listrik yang dialirkan melalui sel saraf motorik menuju sel otot. Rangsangan potensial listrik yang diterima sel otot akan memicu terjadinya proses depolarisasi yang menghasilkan pelepasan ion kalsium di sepanjang serat otot. Ion kalsium berperan dalam pengendalian ikatan filament aktin dan miosin yang menghasilkan kontraksi dan relaksasi otot. Kontraksi dan relaksasi inilah yang menyebabkan tubuh dapat bergerak dan berpindah [1].
Sistem gerak tubuh manusia terdiri dari saraf motorik dan otot rangka dinamakan sistem Neuromuscular. Gangguan pada sistem neuromuscular mengakibatkan gangguan pada aktivitas gerak tubuh manusia. Gangguan neuromuscular dapat terjadi pada sel saraf yang dinamakan Neuropathy dan pada sel otot yang dinamakan Myopathy. Neuropathy merupakan kerusakan sel saraf yang disebabkan oleh gangguan metabolisme, defisiensi nutrisi, racun, obat-obatan tertentu, infeksi virus dan bakteri, gangguan autoimun serta cedera fisik yang berakibat pada berkurangnya kemampuan sel saraf dalam mengalirkan rangsangan dari otak menuju otot. Neuropathy dapat terjadi pada dendrit, akson, maupun selubung mielin pada sel saraf. $M y$ opathy merupakan kerusakan pada sel otot yang disebabkan oleh ketidakmampuan otot untuk berkontraksi akibat dari penyusutan pada otot, kelemahan otot, infeksi virus, bakteri dan parasit serta cedera pada otot. Myopathy dapat terjadi pada otot tangan, otot kaki bahkan otot wajah serta bagian tubuh lainnya. Neuropathy dan Myopathy dapat bersifat genetika atau keturunan[2].

Prevalensi kasus gangguan neuromuscular tahun 19902014 sebesar 160/100.000 atau 1 dari 625 populasi dunia mengalami 1 dari 30 jenis gangguan neuromuscular[3], di mana prevalensi ini mengalami peningkatan dibandingkan sebelum tahun 1990 sebesar 1 dari 3500 populasi dunia mengalami 1 dari 11 jenis gangguan neuromuscular [4].

Penyebab dan lokasi kerusakan yang berbeda pada $\mathrm{Neu}$ ropathy maupun Myopathy akan menghasilkan jenis gangguan yang berbeda dan mengakibatkan penanganan serta pengobatan yang berbeda pula, sehingga sangat penting untuk mendiagnosis secara tepat jenis gangguan neuromuscular yang dialami. Diagnosis suatu penyakit dapat diamati berdasarkan gejala yang ditimbulkan. Namun, gejala Neuropathy dan Myopathy sulit dibedakan karena memiliki gejala yang hampir sama, yakni otot lemas yang mengakibatkan kesulitan berdiri, nyeri, kram, kaku, dan kesemutan pada otot, mati rasa pada bagian tubuh tertentu, serta hilang 
kendali terhadap otot seperti kesulitan menggenggam dan bergerak.

Salah satu metode yang digunakan untuk mendiagnosis gangguan pada sistem neuromuscular adalah metode elektrodiagnostik, yakni metode diagnostik yang menganalisis aktivitas kelistrikan otot menggunakan alat khusus yang dinamakan Electromyography (EMG). Rekaman sinyal EMG dianalisis karakteristik sinyal yang dihasilkan untuk mendiagnosis jenis gangguan neuromuscular yang dialami[5].

Analisis sinyal EMG terdiri dari beberapa tahap yakni akuisisi data, pra-proses, karakterisasi, dan klasifikasi. Analisis sinyal EMG dengan karakterisasi menggunakan metode dekomposisi Wavelet Daubechies orde 4 (Db-4) ke dalam 5 level dekomposisi dengan fitur ekstraksi entropy yakni Shannon, Spektral dan Approximate menggunakan metode klasifikasi Support Vector Machine (SVM) menghasilkan akurasi fitur shannon lv-1 sebesar 90\%, spektral lv-1 100\%, dan approximate lv-3 90\%[6]. Metode karakterisasi lain menggunakan variasi fitur statistik Standar deviasi (STD), peak-to-peak dan Root Mean Square (RMS) dengan metode klasifikasi Artificial Neural Network (ANN) menghasilkan akurasi $87 \%$ dan sensitivitas 90\%[7]. Analisis sinyal EMG menggunakan fitur ekstraksi statistik dapat digunakan untuk menentukan fungsi keanggotaan pada sistem klasifikasi Fuzzy Inference System (FIS)[8]. Analisis performa family wavelet menggunakan fitur ekstraksi statistik dan metode klasifikasi SVM menghasilkan family wavelet terbaik untuk analisis sinyal EMG adalah Symlet dan Daubechies untuk sembarang orde[9].

Namun demikian, deteksi Myopathy dan Neuropathy menggunakan Adaptive Neuro Fuzzy Inference System (ANFIS) masih belum banyak didalami. Untuk itu pada artikel ini dipaparkan sistem identifikasi Myopathy dan Neuropathy menggunakan ANFIS dengan fitur EMG berupa transformasi wavelet diskrit. Paparen meliputi diantaranya analisis sinyal EMG pasien sehat, Myopathy dan Neuropathy menggunakan metode dekomposisi wavelet diskrit dengan family wavelet symlet-8 ke dalam 5-level dekomposisi dan variasi ekstraksi fitur statistik yakni RMS dan fitur entropy yakni spektral, approximate dan Singular Vallue Decompotition (SVD). Hasil karakterisasi sinyal kemudian diidentifikasi menggunakan metode klasifikasi ANFIS. Sistem ini merupakan perpaduan Fuzzy Inference System (FIS) [10] yang diaplikasikasikan dalam metode pembelajaran Artificial Neural Network (NN).

\section{METODE}

Metode sistem deteksi kelainan neuromuscular dipaparkan pada Gambar 1. Secara umum masukan (input) dari sistem deteksi ini adalah hasil dekomposisi wavelet dari EMG dengan teknik klasifikasi menggunakan ANFIS. Proses sistem deteksi dijelaskan berikut ini.

\section{A. Data $E M G$}

Data yang digunakan berupa sinyal EMG dari partisipan sehat, pasien dengan gangguan Myopathy dan
Neuropathy. Sinyal ini diperoleh dari database Physionet.org dengan waktu perekaman masing-masing pasien adalah 12 detik, 27 detik dan 37 detik serta frekuensi sampling $4000 \mathrm{~Hz}$ untuk setiap sinyal[11].

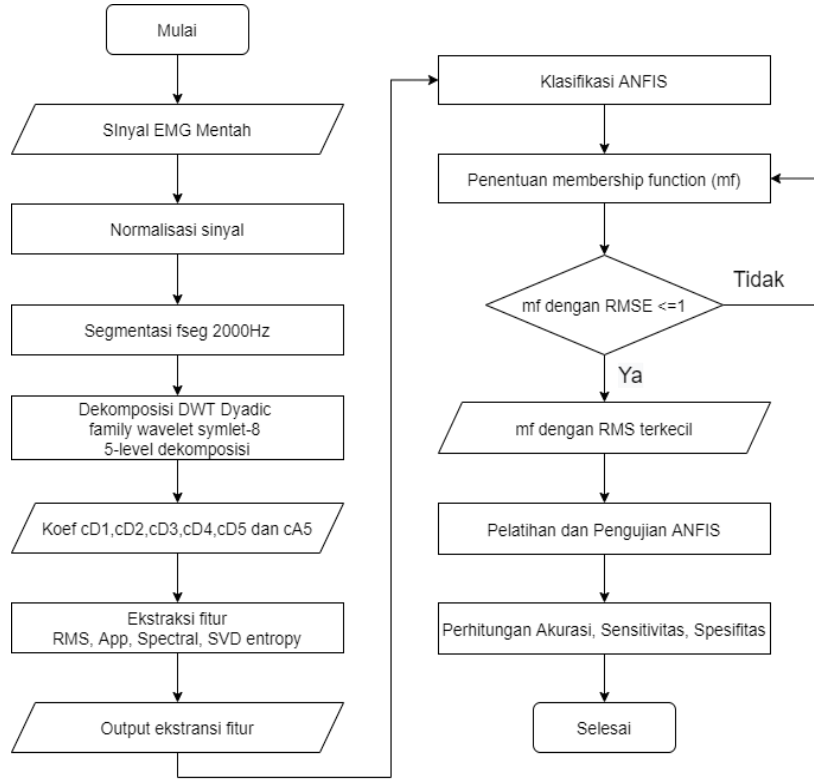

Gambar 1. Skema sistem deteksi kelainan neuromuscular

\section{B. Normalisasi dan Segmentasi}

Sinyal EMG mentah di normalisasi untuk menghilangkan komponen sinyal negatif sekaligus mengubah rentang sinyal menjadi antara 0 sampai dengan 1 , menggunakan persamaan (1) :

$$
x_{n}=\frac{\left(x_{i}-x_{\min }\right)}{\left(x_{\max }-x_{\min }\right)}
$$

Dimana $x_{n}=$ data normalisasi; $x_{i}=$ data ke-i; $x_{\max }=$ data terbesar; $x_{\text {min }}=$ data terkecil. Sinyal normalisasi kemudian disegmentasi dengan frekuensi segmen adalah $1 / 2$ frekuensi sampling menjadi $2000 \mathrm{~Hz}$.

\section{Dekomposisi Menggunakan Wavelet}

Tiap segmen didekomposisi menggunakan metode dekomposisi wavelet diskrit dyadic dengan family wavelet symlet-8 ke dalam 5-level dekomposisi. Koefisien dekomposisi yang digunakan adalah semua koefisien detail (cD1, cD2, cD3, cD4, cD5) dan koefisien aproksimasi ke-5 (cA5). Dekomposisi sinyal dilakukan menggunakan library open source python PyWavelets oleh Gregory.R (2019)[12].

Masing-masing koefisien dekomposisi kemudian di karakterisasi menggunakan variasi fitur statistik yakni RMS dan fitur entropy yakni spektral, approximate, dan SVD (Singular Vallue Decompotition). Ekstraksi fitur entropy dilakukan menggunakan library open source python antroPy [13].

\section{Klasifikasi Menggunakan ANFIS}

Dalam pemilihan fungsi keanggotaan pada proses fuzzifikasi ANFIS, di mana fungsi keanggotaan berfungsi mengubah nilai masukan sebenarnya ke dalam himpunan fuzzy 
[14]. Fungsi keanggotaan yang digunakan adalah Trimf, Trapmf, Gbellmf, Gaussmf dan Gauss2mf. Fungsi keanggotaan dengan nilai Root Mean Square Error (RMSE) terbaik digunakan dalam sistem dengan perbandingan $80 \%$ data pelatihan dan $20 \%$ data pengujian. Data dalam himpunan fuzzy digunakan sebagai masukan sistem klasifikasi ANFIS yang akan diklasifikasikan menjadi output sinyal sehat, myopathy dan neuropathy. Arsitektur ANFIS yang digunakan digambarkan dalam Gambar 2:

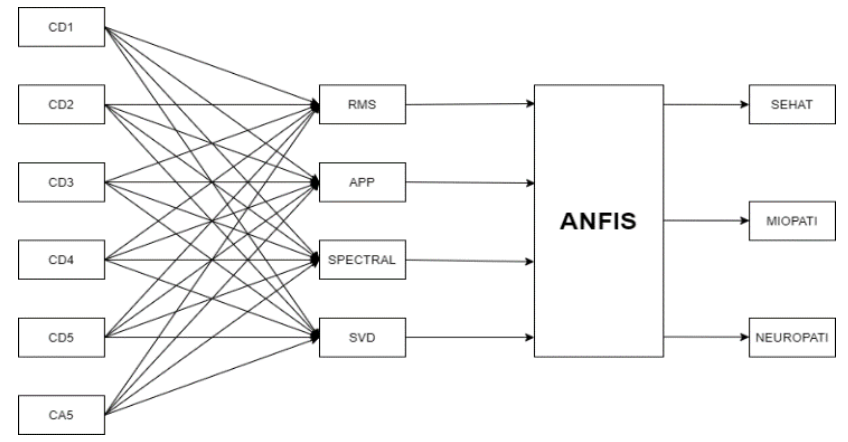

Gambar 2. Arsitektur ANFIS dalam sistem

\section{E. Pengukuran Kinerja}

Kinerja sistem klasifikasi ANFIS di lihat dari parameter akurasi, sensitivitas dan spesivitas. Akurasi menunjukkan persentase sistem dalam mendeteksi sinyal dengan tepat. Sensitivitas atau True positive rate menunjukkan persentase sistem dalam mendeteksi sinyal gangguan neuromuscular dengan tepat. Spesivitas atau True negative rate menunjukkan persentase sistem dalam mendeteksi sinyal sinyal sehat dengan tepat.

Akurasi, sensitivitas dan spesivitas dituliskan dalam persamaan sebagai berikut [15]:

$$
\begin{aligned}
& \text { Akurasi(\%) }=\frac{T P+T N}{T P+T N+F N+F P} \times 100 \% \\
& \text { Sensitivitas(\%) }=\frac{T P}{T P+F N} \times 100 \% \\
& \text { Spesivitas(\%) }=\frac{T N}{T N+F P} \times 100 \%
\end{aligned}
$$

Dimana TP (True positive) menunjukkan sinyal gangguan neuromuscular yang di deteksi dengan tepat, TN (True negative) menunjukkan sinyal sehat yang di deteksi dengan tepat, FP (False positive) menunjukkan sinyal sehat yang di identifikasi sebagai sinyal gangguan neuromuscular, dan FN (False negative) menunjukkan sinyal gangguan neuromuscular yang di identifikasi sebagai sinyal sehat.

\section{HASIL DAN PEMBAHASAN}

Sinyal EMG normalisasi disegmentasi menjadi $25 \mathrm{seg}-$ men sinyal sehat, 55 segmen sinyal myopathy dan 73 segmen neuropathy, di mana setiap segmen mewakili karakteristik sinyal aslinya. Masing-masing segmen didekomposisi menggunakan metode dekomposisi wavelet dyadic dengan family wavelet symlet- 8 ke dalam 5 level dekomposisi, menghasilkan 6 komponen sinyal yang digunakan yakni 5 koefisien detail (cD1, cD2, cD3, cD4, cD5) dan 1 koefisien aproksimasi (cA5). Masing-masing Koefisien dekomposisi di karakterisasi menggunakan fitur ekstraksi RMS (Gambar 3), spectral entropy (Gambar 4), approximate entropy (Gambar 5) dan SVD entropy (Gambar 6).

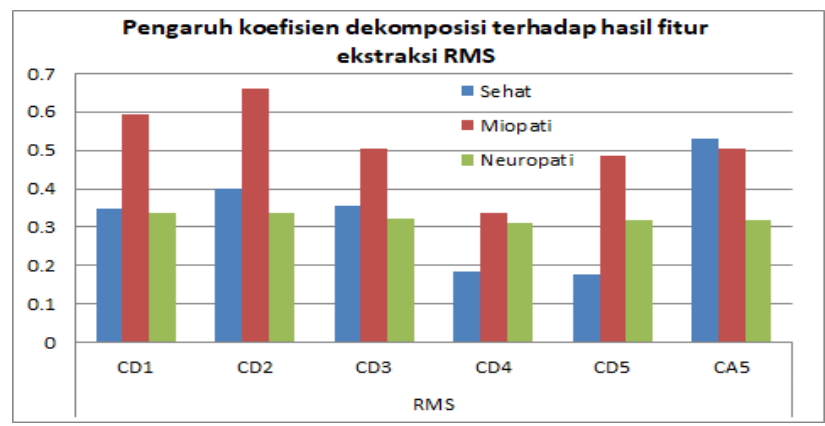

Gambar 3. Karakteristik RMS

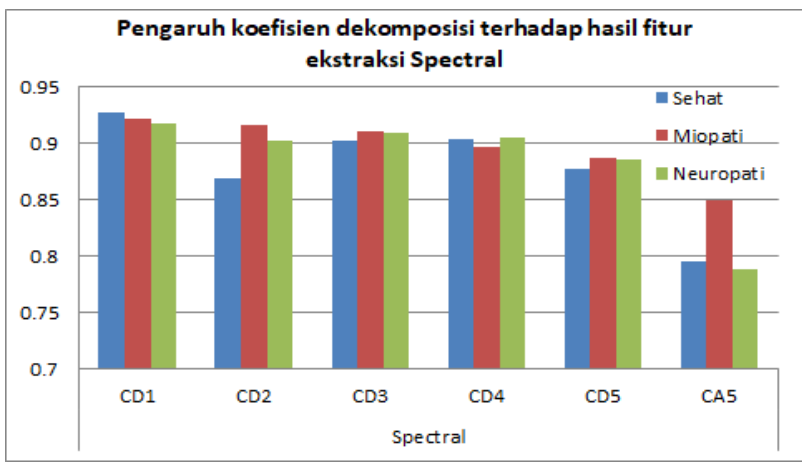

Gambar 4. Karakteristik spectral

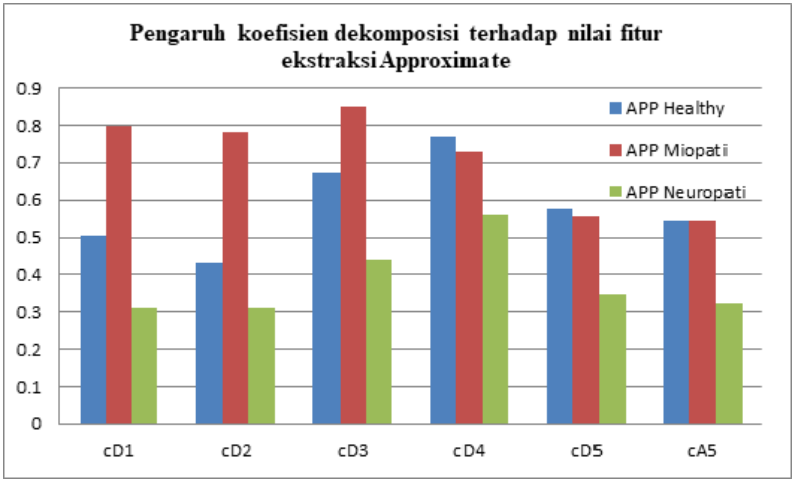

Gambar 5. Karakteristik approximate

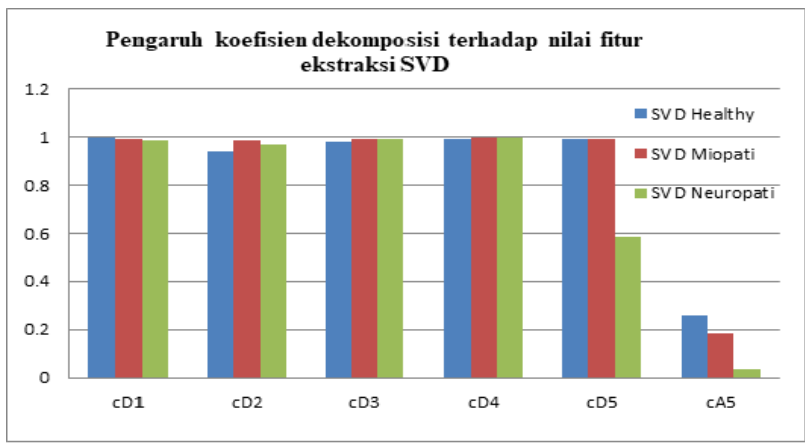

Gambar 6 Karakteristik SVD

Karakteristik sinyal EMG sehat, myopathy dan neuropathy pada setiap koefisien dekomposisi berbeda untuk setiap fitur ekstraksi yang digunakan. Fitur ekstraksi RMS pada Gambar 3. memberikan karakteristik sinyal yang baik 
pada semua koefisien dekomposisi. Fitur RMS (Gambar 5) dan fitur approximate (Gambar 6) memberikan karakteristik sinyal yang lebih baik dari fitur spectral (Gambar 4). Hal ini tampak pada gambar tersebut dimana perbedaan amplitud yang lebih besar antara ketiga kelas (sehat, miopati, neuropati). Fitur ekstraksi approximate pada Gambar 5. memberikan karakteristik sinyal yang baik pada koefisien detail cD1, cD2 dan cD3. Fitur ekstraksi SVD pada Gambar 6. memberikan karakteristik sinyal yang baik hanya pada koefisien aproksimasi cA5.

Nilai karakteristik sinyal EMG dari masing-masing koefisien dekomposisi, di gunakan sebagai masukan dalam sistem klasifikasi ANFIS. Sistem klasifikasi ANFIS digunakan untuk mengklasifikasikan sinyal masukan ke dalam target output sinyal tersebut yakni sinyal sehat (0), myopathy (1) dan neuropathy (2). Dalam sistem klasifikasi ANFIS, fungsi keanggotaan berfungsi untuk mengubah nilai masukan sistem yang berupa nilai tegas menjadi nilai dalam himpunan fuzzy. Pemilihan fungsi keanggotaan dilakukan pada data koefisien aproksimasi cA5, dengan mengamati nilai RMSE pelatihan dan pengujian yang dihasilkan. Diperoleh fungsi keanggotaan dengan nilai RMSE pelatihan dan pengujian terbaik menggunakan fungsi keanggotaan Gauss2mf. Nilai RMSE fungsi keanggotaan dituliskan dalam Tabel 1.

TABEL I

ANALISIS FUNGSI KEANGGOTAAN

\begin{tabular}{|c|c|c|}
\hline $\begin{array}{c}\text { Fungsi } \\
\text { keanggotaan }\end{array}$ & RMSE-train & RMSE-test \\
\hline Trimf & 0,013711 & 0,11983 \\
\hline trapmf & 0,0000066 & 0,20951 \\
\hline gbellmf & 0,0019297 & 0,040169 \\
\hline gaussmf & 0,0040709 & 0,087537 \\
\hline gauss2mf & $\mathbf{0 , 0 0 0 1 3 5 9 2}$ & $\mathbf{0 , 0 2 0 6 4 2}$ \\
\hline
\end{tabular}

Perbandingan hasil keluaran sistem klasifikasi ANFIS terhadap target keluaran sistem untuk data pengujian dan data pelatihan di tampilkan dalam Gambar 7. dan Gambar 8.

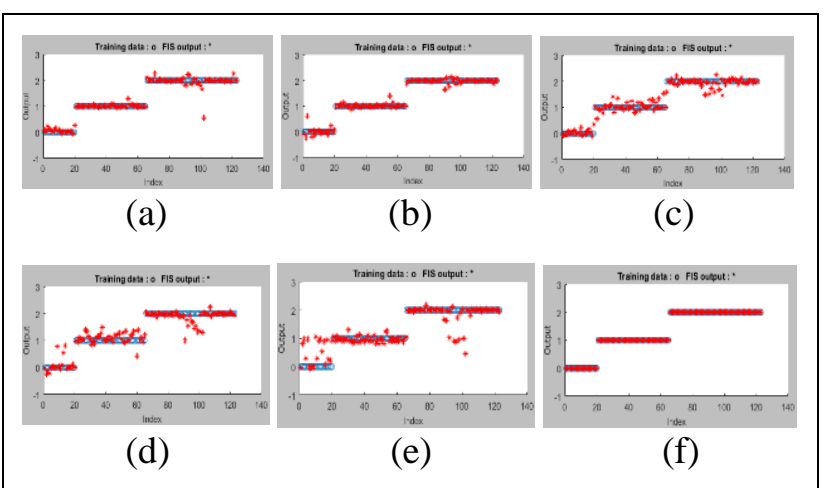

Gambar 7. Pelatihan ANFIS (a) cD1; (b) cD2; (c) cD3; (d) cD4; (e) cD5; (f) $\mathrm{cA} 5$

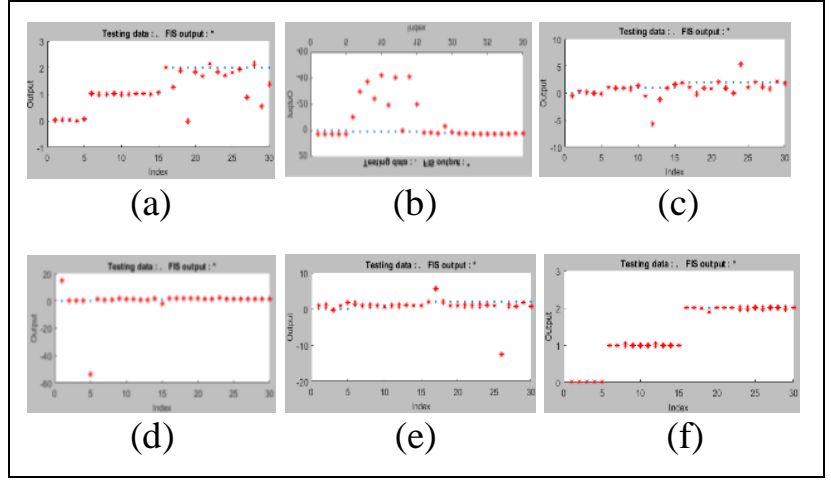

Gambar 8: Pengujian ANFIS (a) cD1; (b) cD2; (c) cD3; (d) cD4; (e) cD5; (f) $\mathrm{cA} 5$

Berdasarkan Gambar 7. dan Gambar 8., performa klasifikasi ANFIS dalam mengidentifikasi sinyal EMG sehat dan sinyal EMG dengan gangguan neuromuscular menghasilkan nilai akurasi, sensitivitas dan spesivitas untuk data pelatihan pada Tabel 2 dan data pengujian pada Tabel 3:

TABEL II

KINERJA PELAIHAN

\begin{tabular}{|c|c|c|c|}
\hline $\begin{array}{c}\text { Koefisien } \\
\text { dekomposisi }\end{array}$ & $\begin{array}{c}\text { Akurasi } \\
(\mathbf{\%})\end{array}$ & $\begin{array}{c}\text { Sensitivitas } \\
(\mathbf{\%})\end{array}$ & $\begin{array}{c}\text { Spesivitas } \\
(\mathbf{\%})\end{array}$ \\
\hline $\mathrm{cD} 1$ & 99,19 & 99,03 & 100 \\
\hline $\mathrm{cD} 2$ & 99,19 & 100 & 95 \\
\hline $\mathrm{cD} 3$ & 97,56 & 97,09 & 100 \\
\hline $\mathrm{cD} 4$ & 91,87 & 93,20 & 85 \\
\hline $\mathrm{cD} 5$ & 86,18 & 93,20 & 50 \\
\hline cA5 & $\mathbf{1 0 0}$ & $\mathbf{1 0 0}$ & $\mathbf{1 0 0}$ \\
\hline
\end{tabular}

TABEL III KINERJA PENGUJIAN

\begin{tabular}{|c|c|c|c|}
\hline $\begin{array}{c}\text { Koefisien } \\
\text { dekomposisi }\end{array}$ & $\begin{array}{c}\text { Akurasi } \\
(\boldsymbol{\%})\end{array}$ & $\begin{array}{c}\text { Sensitivitas } \\
(\boldsymbol{\%})\end{array}$ & $\begin{array}{c}\text { Spesivitas } \\
(\boldsymbol{\%})\end{array}$ \\
\hline cD1 & 83,33 & 80 & 100 \\
\hline cD2 & 90 & 92 & 80 \\
\hline cD3 & 56,66 & 48 & 100 \\
\hline cD4 & 53,33 & 48 & 80 \\
\hline cD5 & 46,66 & 52 & 20 \\
\hline cA5 & $\mathbf{1 0 0}$ & $\mathbf{1 0 0}$ & $\mathbf{1 0 0}$ \\
\hline
\end{tabular}

\section{KESIMPULAN}

Pada artikel ini telah dipaparkan sistem deteksi gangguan neuromuscular. Sistem deteksi menggunakan ANFIS dengan fitur EMG berupa karakteristik dari wavelet diskrit. Sistem deteksi menggunalan fitur RMS dan SVD untuk koefisien aproksimasi dan fitur ekstraksi Approximate memberikan kinerja yang lebih tinggi. Sedangkan untuk fitur spektral menghasilkan karakteristik sinyal yang lebih rendah dibanding dengan fitur yang lain. Performa sistem klasifikasi ANFIS dalam mengidentifikasi sinyal EMG sehat dan gangguan neuromuscular menggunakan 4 variasi fitur RMS, spektral, approximate, dan SVD menghasilkan performa terbaik pada koefisien aproksimasi cA5 yakni akurasi $100 \%$, sensitivitas $100 \%$ dan spesivitas $100 \%$. Berdasarkan hasil karakterisasi sinyal dan klasifikasi sinyal, identifikasi sinyal EMG dengan dekomposisi wavelet dyadic dengan family wavelet Symlet- 8 ke dalam 5 
level dekomposisi baik menggunakan koefisien aproksimasi ke-5 dengan variasi fitur RMS dan SVD.

\section{REFERENSI}

[1] Rahyusalim. (2018). Intra-Operative Nerve Monitoring Dalam Praktik Klinis Edisi Pertama. Depok : Media Aesculapius.

[2] Michell.A.W,. (2013). Understanding EMG. Cambridge UK : Oxford University Press.

[3] Deenen.J.C., Horlings.C.G., Verschuuren.J.J., Verbeek.A.L., \& van Engelen.B.G. (2015). The Epidemiology of Neuromuscular Disorders: A Comprehensive Overview of the Literature. Journal of neuromuscular diseases, 2(1), 73-85.

[4] Emery A. E. (1991). Population frequencies of inherited neuromuscular diseases a world survey. Neuromuscular disorders (NMD), 1(1), 19-29.

[5] Weiss, L., Weiss, J., \& Julie Silver. (2004). Easy EMG: A Guide to Performing Nerve Conduction Studies and Electromyography. London : Elsevier Inc.

[6] Bhuvanesari, P., \& Kumar, J.S. (2014). Classification of electromyography signal using wavelet decomposition method. IEEE International Conference on Computational Inteligence and Computing Research, December 18-20, Coimbatore India.

[7] Singh, A., Dutta, M.K., \& Travieso, C.M. (2017). Analysis of EMG Signals for Automated Diagnosis of Myopathy. $4^{\text {th }}$ IEEE Uttar Pradesh Section International Conference on Electrical, Computer and Electronics (UPCON), 628-631.

[8] Robinson, C.G., \& Chandrasekaran, R. (2018). FIS Based Abnormality Classification. International Journal of Research in Engineering, IT and Social Science, Des 19, Vol 08(12), 101-110.

[9] Achmamad, A., \& Jbari, A. (2020). A comparative study of wavelet families for electromyography signal classification based on discrete wavelet transform. Bulletin of Electrical Engineering and Informatics, 9(4), 1420-1429.

[10] Nuryani, N., Ling, S. H., \& Nguyen, H. T. (2012, June). Hybrid particle swarm-based fuzzy support vector machine for hypoglycemia detection. In 2012 IEEE International Conference on Fuzzy Systems (pp. 1-6).

[11] Goldberger, A.L., Amaral, L.A., Glass, L., Hausdorff, J.M., Ivanov, P.C., Mark,R.G.,... Stanley, H. E. (2000). PhysioBank, PhysioToolkit, and PhysioNet: components of a new research resource for complex physiologic signals. Circulation, 101(23), E215-E220.

[12] Gregory R.L, Gommers, R., Wasilewski, F., Wohlfahrt, K., O'Leary, A. (2019). PyWavelets: A Python package for wavelet analysis. Journal of Open Source Software, 4(36), 1237.

[13] Raphael, V,. Tsang, J.M.F., Yadav, P.S., \& Kapetanovic, A.L. (2018). EntroPy 0.1.0: A python package for analisis entropy fitur extraction. Raphaelvallat.com/antropy

[14] Nuryani, N., \& Nugroho, A. S. (2019), Identification of atrial fibrillation using descriptive statistic features and adaptive Neuro-Fuzzy inference system. Journal of Physics: Conference Series Vol. 1153, No. 1, p. 012043)

[15] Afdala, A., Nuryani, N., \& Nugroho, A. S. (2017). Automatic Detection of atrial fibrillation using basic Shannon entropy of RR Interval feature. In Journal of Physics: Conference Series, Vol. 795, No. 1, p. 012038 . 